\title{
SZAKFELÜGYELET ÉS/VAGY TANFELÜGYELET? - A MAI MAGYAR HELYZET
}

\author{
KIRÁLY ZSOLT \\ az Eötvös Loránd Tudományegyetem Bölcsészettudományi Karának \\ adjunktusa \\ kiraly.zsolt@btk.elte.hu
}

Kevés olyan fogalom van a közoktatás tárgykörében, amelyet olyan sokan - a laikus közvéleményen és a sajtón kívül ideértve még az e területen dolgozók nem kis részét is - félreértenének, mint a tanfelügyelet-szakfelügyelet kérdését.

Ha megnézzük az elmúlt három évben megjelent médiahíreket, valamint az azokhoz füzött olvasói kommentárokat, azonnal föltünik, hogy a közlemények döntő többsége a tanfelügyeletet szinte kizárólag csak szakfelügyeletként, azaz a tanárok munkájának ellenőrzéseként fogja fel, és legfontosabb feladatának a nem megfelelő szaktanári és egyéni pedagógiai teljesítmények azonosítását látja. Ez a szemlélet azt sugallja, hogy az oktatás minden bajának a pedagógusok gyenge szakmai-morális színvonala és/vagy alacsony színvonalú teljesítménye az oka, és - jobb esetben szűklátókörüségből, rosszabb esetben számításból - a felelősséget a lehető legalacsonyabb (és legkiszolgáltatottabb) szintre igyekszik hárítani. Szerencsére azonban, elvétve ugyan, de komoly, szakmai szempontból is értékes, a problémát világosan érzékelö és széles látókörüen megközelítő hozzászólásokkal is lehet találkozni, mint például Radó Péter: Elöre vagy hátra? A szak-/tanfelügyeletről címü írása és az ahhoz Nahalka Istvántól és Singer Pétertől érkezett bejegyzések az OktpolCafé oktatáspolitikai blogján (Radó, 2010).

Könnyen lehet, hogy az alapvetö félreértést a Sólyom László által életre hívott Bölcsek Tanácsa Alapítvány 2009-es Szárny és teher - Ajánlás a nevelés-oktatás rendszerének újjáépitésére és a korrupció megfékezésére címet viselő, és az akkori ellenzék - okkal, ok nélkül - oktatásügyi programjának tekintett dokumentum megfogalmazásai (vagy azok félreértelmezése) erősítették fel igazán (Bölcsek Tanácsa Alapitvány, 2009). A korabeli sajtóközlemények, így például az Új Katedra címü szakfolyóirat is, a kérdéssel kapcsolatos reformjavaslatok közül azt emelték ki, hogy „A bölcsek újra megszerveznék a szakfelügyeletet, amelynek legfontosabb feladata a pedagógusok külső, iskolától független értékelése lenne, (...). A differenciált értékelésnek - az ajánlás szerint - következményekkel kell járnia mind pozitív, mind negatív oldalon. Az értékeléshez szorosan kapcsolódna a minőségalapú, differenciált bérezés, amelynek megvalósításához a közalkalmazotti státus átalakítása elengedhetetlennek tünik. A pozitív következmények között sorolja továbbá 
a dokumentum - többek között - a minőségalapú jutalmazást, a kulturális és szakmai továbbképzési utak lehetőségét, a fizetett alkotói szabadságot, a kutatói ösztöndíjakat. Az értékelés ugyanakkor negatív következménnyel is járhatna: a szerzök szerint szükséges a nem elfogadható színvonalú teljesítmények - a korrekcióra, javításra szolgáló időszakot követő - szankcionálása, ami megjelenhet a fizetés csökkentésében vagy az alkalmatlannak bizonyuló, tartósan gyenge színvonalon dolgozó pedagógusok munkaviszonyának átalakításában, esetleg elbocsátásában.” (Új Katedra, 2010)

Hasonló szemlétet rajzolódott ki a 2010 februárjában a Népszavának nyilatkozó Sió László, a Fidesz oktatási kabinetjének vezetője szavaiból is, amelyeket a lap így interpretált: „,...) a Fidesz elbocsátaná az alkalmatlan pedagógusokat. Az oktatáspolitikus egy komplex, külső pedagógusértékelési rendszerről beszélt, amelynek egy eleme vagy esetleges következménye a tanári állás megszűntetése egyes alkalmatlan pedagógusoknál.” Ezektől a kijelentésektől aztán a Fidesz később elhatárolódott, mondván, hogy mindez csak a politikus magánvéleménye, azonban még ugyanazon a héten nyilvánosságra került Hoffmann Rózsának, az Emberi Erőforrások Minisztériumának oktatásért felelős későbbi államtitkárának egy lakossági fórumon elhangzott nyilatkozata, mely szerint „Új mozzanat a mi elgondolásunkban, hogy a pedagógusok munkáját szakemberek kívülről, objektíven ellenőrzik (...) ebben az is benne van, hogy az a pedagógus, aki nem képes fejlödni, aki nem képes a munkáját magas színvonalon végezni, attól a szakmának meg kell válni." (Népszava Online, 2010)

Az új kormány hatalomra kerülése után azonban, jól érezhetően „menet közben" tanulva, a kormányzati nyilatkozatok döntő többsége már az előbbieknél jóval árnyaltabban, a tanfelügyelet tágabb kontextusában szemléli a kérdést. Jó példa erre a szemléletváltásra az Oktatási Hivatal honlapján készült interjú a közoktatásért felelős államtitkárral, amelynek már a címe is erről tanúskodik: „A megerősítés és a fejlesztés a cél." (Hoffmann, 2012) Az előzmények ismeretében mindenesetre nem különösebben meglepő, hogy a kormányzati nyilatkozatok kiegyensúlyozottabbá válása a laikus közvéleményt reprezentáló Magyarországi Szülők Országos Egyesületét (MSZOE) arra késztette, hogy felhívja az illetékesek figyelmét arra, hogy „a tanfelügyelet mellett létre kell hozni a tantárgyi szakfelügyeleti rendszert, és a nem megfelelő minősítésű iskolák vezetőit le kell váltani, a pedagógiai munkára alkalmatlan pedagógusokat el kell távolítani a pályáról.” (http://www.delmagyar.hu/, 2013)

A magyar tan- és szakfelügyeleti rendszer újragondolása mindig is az egész nevelési-oktatási rendszer újjáépítésének egyik fontos elemeként jelent meg a hajdani ellenzék, a mai magyar kormány gondolkodásában. Az igény már egyértelmüen megfogalmazódik a Bölcsek Tanácsa 2009-es Szárny és teher címü dokumentumában is, amely abból a premisszából indul ki, hogy „Magyarország azon ritka országok közé tartozik, ahol nem létezik a nevelési-oktatási intézmények rendszeres és szakmailag ellenőrzött színvonalú, külső értékelése. A fenntartók által leg- 
alább négyévente elvégzendő értékelések sok helyütt nem valósulnak meg ténylegesen, formálisak, az elkészült értékelésekből a szervezetfejlesztő, komplex látásmód sokszor hiányzik. Az intézmények értékelésében a pedagógusok felkészültségének, rátermettségének, a tanulói és pedagógusi attitüdnek, motivációnak és az intézmény közösségformáló, jellemfejlesztő, nevelőerejének az értékelése kevéssé kap helyet." (Bölcsek Tanácsa Alapítvány, 2009, 68-69. o.)

Az tény, hogy formális, központosított szakfelügyelet 1985-ös oktatási törvény óta nem müködik Magyarországon. Ekkor alakították át a szakfelügyelet szaktanácsadássá a megyei pedagógiai intézetek felügyelete alatt, így az iskolák törvényes müködésért és a szaktanári-pedagógiai ellenőrzéséért és értékeléséért az iskola fenntartója vette át a felelősséget, úgy, hogy az ellenőrzés (pénzügyek, törvényesség stb.) a fenntartóhoz, az értékelés (pedagógiai, szaktárgyi munka stb.) pedig az iskolákhoz került, önértékelés formájában. A 1993-as közoktatási törvény rendelkezett az országos szakértői lista létrehozásáról, majd a 2000-es évektől először pályázati forrásokat, majd később normatívát is rendeltek az ellenőrzési és értékelési szolgáltatások igénybe vételére. Az 1993-as közoktatási törvény 1999-es kiegészítése (40. §) kötelezővé tette, hogy az iskolák 2002 után vezessenek be valamiféle belső minőségbiztosítási rendszert, amelynek része volt egy tanári teljesítményértékelő elem, a közalkalmazottak jogállásáról szóló törvény pedig előírta a pedagógusok minősítését is. Pályázni lehetett a Comenius 2000 közoktatási minőségfejlesztési programra, müködött egy szakértői értékelési rendszer is például az iskolai pedagógiai program vizsgálatára, valamint megszervezték az országos mérés-értékelési rendszert (kompetenciamérés) is. A közoktatási törvény 2003-as módosítása után pedig a fenntartó köteles volt nyilvánosságra hozni az iskolák munkájával kapcsolatos négyévenkénti értékeléseket. Tehát azt nem lehet mondani, hogy egy negyedszázada semmiféle minőségellenőrzés nem müködik Magyarországon, de az igaz, hogy nem rendszeres, és hiányzik az intézményértékelés egységesített eljárásrendje és tartalma sem standardizált, így kétségtelenül szükség van a kérdés rendezésére.

Kívülröl úgy tünik, hogy az oktatási kormányzat a rendszer újjászervezésével kapcsolatos álláspontja a mai napig (2013. március 15.) nem teljesen kristályosodott ki, és a végleges koncepció kialakítása csak a nyilvánvalóan még most is kidolgozás alatt álló és a bevezetés tervezett időpontjához képest komoly késéssel megszülető szakértői anyagok alapján fog megtörténni. Az ebben a pillanatban a nagyközönség számára kirajzolódó kép - bár még nagyon sok kulcsfontosságú részlet tisztázásra vár - azt sugallja, hogy a kormányzat egy erősen központosított, a megyei kormányhivatalokhoz rendelt pedagógusi és intézményi értékelő (azaz egyszerre tan- és szakfelügyeleti jellegü), alapvetően minősítő célzatú rendszert szándékozik bevezetni 2013 szeptemberétől. Ennek elsőrendủen deklarált célja az lenne, hogy segítse az iskolákat a lehető legjobb teljesítmény elérésében, de - alig titkoltan kiemelt szerepet szán annak, hogy - egyelöre ismeretlen elvek és szempontrendszer alapján, ismeretlen szakmai hátterü felügyelöi testület segítségével - rendsze- 
resen, mintegy hatóságilag ellenőrizze a pedagógusokat, akiknek szakmai besorolása és így bére, valamint munkaviszonyának puszta megmaradása is ezektől az ellenőrzésektől fog függni.

\section{Irodalom}

Bölcsek Tanácsa Alapítvány (2009): http://mek.niif.hu/07900/07999/pdf/szarny_es_teher.pdf

Új Katedra (Pedagógusok Lapja) (2010): február, Commitment Kommunikációs Iroda Kft. http://www.ujkatedra.hu/ujkatedra/kiemelt-cikkeink/szarny-teher-bolcsek

Népszava Online (2010) július 12. Szakfelügyelet dönthet a pedagógusbérekröl http://www.nepszava.hu/articles/article.php?id=322157

Hoffmann Rózsa (2012): A megerösités és a fejlesztés a cél; Interjú az Emberi Eröforrások Minisztériumának oktatásért felelös államtitkárával a köznevelési intézmények ellenörzéséröl. 2012. október 15., Oktatási Hivatal http://www.oktatas.hu/kozneveles/projektek/tamop318_minosegfejl/projekthirek/hoff mann_intezmeny_ellenorzesrol/

Delmagyar.hu (2013): MSZOE: tantárgyi szakfelügyeleti rendszert is létre kell hozni. 2013. január http://www.delmagyar.hu/belfold_hirek/mszoe_tantargyi_szakfelugyeleti_rendszert_is letre_kell_hozni/2316629/

Radó Péter (2010): Elöre vagy hátra? A szak-/tanfelügyletröl http://oktpolcafe.hu/elore-vagy-hatra-a-szak-tanfelugyeletrol-848/ 